\title{
Adding Benzene to Fire: Overlapping Seasonality as a Pull Factor to Producer Prices in Ethiopia
}

\section{Kindie Getnet}

\author{
Department of Marketing, Ambo College, Jima University, Ethiopia \\ E-mail: k-getnet@cgiar.org
}

\begin{abstract}
Coupled with the seasonal nature of agricultural production, seasonality of farmers' cash demand influences the level of actual market supply and price of agricultural products. This study investigates the seasonal behaviours of producer prices and farmers' cash demand for two crops (white teff and white wheat) that serve as staples and sources of cash income around Ambo, Ethiopia. Descriptive studies on price time series show that producer prices for the two crops get low during the harvest and immediate post harvest seasons and survey results show that most farmers have a high demand for cash during same seasons and, as a result, sell a great proportion of their marketable stock of the two crops during such seasons. This creates overlapping seasonality between agricultural production, on the one hand, and high cash demand of farmers, on the other. This overlapping seasonality due to the high cash demand of farmers is expected to aggravate the seasonal decline of producer prices already resulted from the seasonal supply of agricultural production. A most likely policy implication, to raise and stabilize producer prices, is therefore to influence the seasonal behaviour of farmers' high cash demand in such a way that it coincides with the lean seasons of agricultural supply. This could be approached through rescheduling the time of fertilizer debt and land use tax payment, those important factors that put farmers into selling a large proportion of their marketable crops during such seasons of low producer prices. By raising and stabilizing farmers' income from crop sales, such policy will promote the economic incentive of smallholder farmers to increase their productivity.
\end{abstract}

Keywords: Producer Price; Farmers' Cash Demand; Overlapping Seasonality; Sub-Saharan Africa; Ethiopia

\section{Introduction}

A large volume of literature on the evaluation results of the market reform process implemented in Sub-Saharan Africa countries witness a shortfall in achieving the outcomes expected from the reform process (for example, Badiane, 2000; Thorbeke, 2000; Kherallah et al., 2002). The agricultural supply response, especially that of food crops, is found very limited to abate the problem of chronic food insecurity challenging the people in the region. While a number of factors might be held accountable for this limited supply response, underdevelopment of domestic agricultural markets (or market failure) in the sense of lacking basic premises to enable a wider participation of the private sector through transaction cost reduction and through vested risk management and risk absorption capacity remains undoubted explanatory factor for much of the shortfall. The resulting price levels and variability affect the choice set and decisions of farmers, which, in turn, determine the productivity and supply response of farmers to the market reform process.

The results of price response analyses towards understanding whether the previously suppressed agricultural prices in the developing countries shifted positively following the market liberalization are inconclusive. In fact, Sahn et al. (1996), Seppala (1997), Valdes (1996), and Badiane (2000) found quite similar results about agricultural product prices after the market reform. Sahn et al. (1996) concluded that the real producer prices of cash crops and tradable food crops did not show proportionate rise to the level of devaluation, which is one of the liberalization measures. Seppala (1997), from his comparative study in Sub-Saharan Africa countries, concluded that liberalization is accompanied by a decline in real prices of food crops, in some countries, and by a moderate increase in others. In an analysis of producer prices between 1986 and 1995, Valdes (1997) found that all major producer prices had declined in real terms, in seven out of eight Latin American countries, following market liberalization. Results due to Alderman and Shively (1996), for the real wholesale Ghanaian food prices, evidence a continuously downward trend in the post-reform period. Badiane (2000), in his study of the effects of market reforms on local market prices for Benin, Malawi, and Ghana (six regional markets for each country), found that rural prices in most markets have declined during the market reform period.

Whereas market failure might be part of the problem, the seasonality of agricultural production and seasonality of farmers' cash demand may also contribute towards decline in agricultural product prices. Since food crop production is rooted in the biological process of agricultural production, seasonality is a common phenomenon in agricultural production, supply, and price. As a matter of fact, agricultural prices tend to be seasonally low during the harvest and immediate post-harvest seasons even for storable products, typically so where the role of market to promote temporal arbitrage is limited. In absence or limitation of other income sources, seasonal cash demand of farmers puts them into selling much of their 
marketable crop surplus within a certain period of time to fulfil their quick cash requirements. This becomes a potential source for major price decline when it overlaps with the season of low agricultural prices (i.e., the season of high agricultural product supply).

As a result of transformations in traditional agriculture (from subsistence to semi-commercial agriculture), cash requirements of smallholder farmers are growing even among those producing mainly food crops (Getnet, 2005). As such, it might be necessary to assess the role of farmers' seasonal cash requirement in terms of influencing the market supply of products and, thereby, agricultural prices and farmers' economic incentives. The investigation would help to generate useful information to guide intervention so as to influence the pattern of farmers' seasonal cash demand in such a way that it does not overlap with the season of low agricultural prices (the season of high agricultural product supply). This study tries to address such issues around Ambo (Ethiopia) based on information generated from secondary data with regard to the seasonal behaviours of producer prices and from primary data with regard to the seasonality of farmers' cash demand, for two staples in the country, namely white teff and white wheat.

The remaining part of the paper is organized as follows: First, the seasonal behaviours of producer prices are investigated using descriptive methods. Second, survey results on farmers' seasonal cash requirements and perceptions on price seasonality are discussed together with the main factors affecting their cash demand. Finally, conclusions and policy implications are set forth.

\section{The Seasonal Behaviours of Producer Prices}

The analysis on the seasonal behaviour of producer prices is based on real producer price data of white teff (PWT) and real producer price data of white wheat (PWW) observed at monthly frequencies starting from 1996M1 to 2000M2 in a typical grain market (Ambo), a surplus production area located in central west Ethiopia. The time period is chosen on the basis of availability of continuous monthly price data in the post-liberalization period along with country level consumer price indices useful to adjust the price data for possible inflation (deflation) to obtain real producer prices.

The seasonal property of the real producer price series for each crop was identified using the seasonal dummy coefficient method in which the sign and magnitude of a dummy coefficient for a month indicate the position and importance of a given month's departure from the month considered as a reference. For example, if January is considered as a reference month in terms of exhibiting very low producer prices (so is the case in this study $)^{1}$, the rest of the months are expected to depart from it positively but with different magnitude of departure depending on their closeness to $\mathrm{it}^{2}$. Whereas those months near to January are expected to have similar properties, hence limited magnitude of departure (because more or less demand and supply situations in such months remain the same like that of January), those months distant from January are expected to have different properties and hence significant magnitude of departure. Accordingly, the resulting information can be used to have useful insight into the seasonal properties of the producer prices. Table 1 shows the relative position and magnitude of departure of prices in the rest of the months from that of the reference month, January, which is considered as a constant in the specification and estimation procedure.

Since the coefficients reflect the magnitude of deviation of each respective month's price from that of January's price (the reference month with the lowest producer price), months with nearly similar seasonal behaviour to that of January have only small deviation from that of the January's price (hence small magnitude of seasonal dummy coefficient). If deviations have small magnitude, $t$-ratios also become insignificant. This is typically true for December, February, March, April, and May in the case of each crop, with November added for that of white wheat. Hence, it could be argued that these months have seasonal effect on producer prices with no significant difference from that of January's price whereas the rest of the months show seasonal behaviour with significant difference from that of the reference month's price. Accordingly, December, January, February, March, April, and May (harvest and immediate post-harvest seasons) could be considered as months in which real producer prices for white teff and white wheat are low, relatively speaking, with November included in the case of white wheat. On the other hand June, July, August, September, and October (lean seasons) could be considered as months in which real producer prices for white teff and white wheat are high, relatively speaking, with November excluded in the case of white wheat.

Additional information about the seasonal behaviours of producer prices could also be obtained by isolating the seasonal component of prices from other components using the classical multiplicative model techniques of time series data decomposition into trend, cyclical, seasonal, and irregular components. Using this descriptive approach, the Grand Seasonal Index (GSI) of each month (which is the indicator of the seasonal properties of the real producer prices) is obtained by averaging the ratio-to-moving average of each month observed over the five years (1996M1 to 2000M12). Then, the seasonal properties of real producer prices could be understood by observing the position of such GSI figures of each month vis-à-vis the annual average producer price observed over the sample period. GSI for some months fall below the annual average and for other months fall above the annual average ${ }^{3}$. 
Table 1. Seasonal dummy coefficients of real PWT and real PWW (1996M1-2000M12)

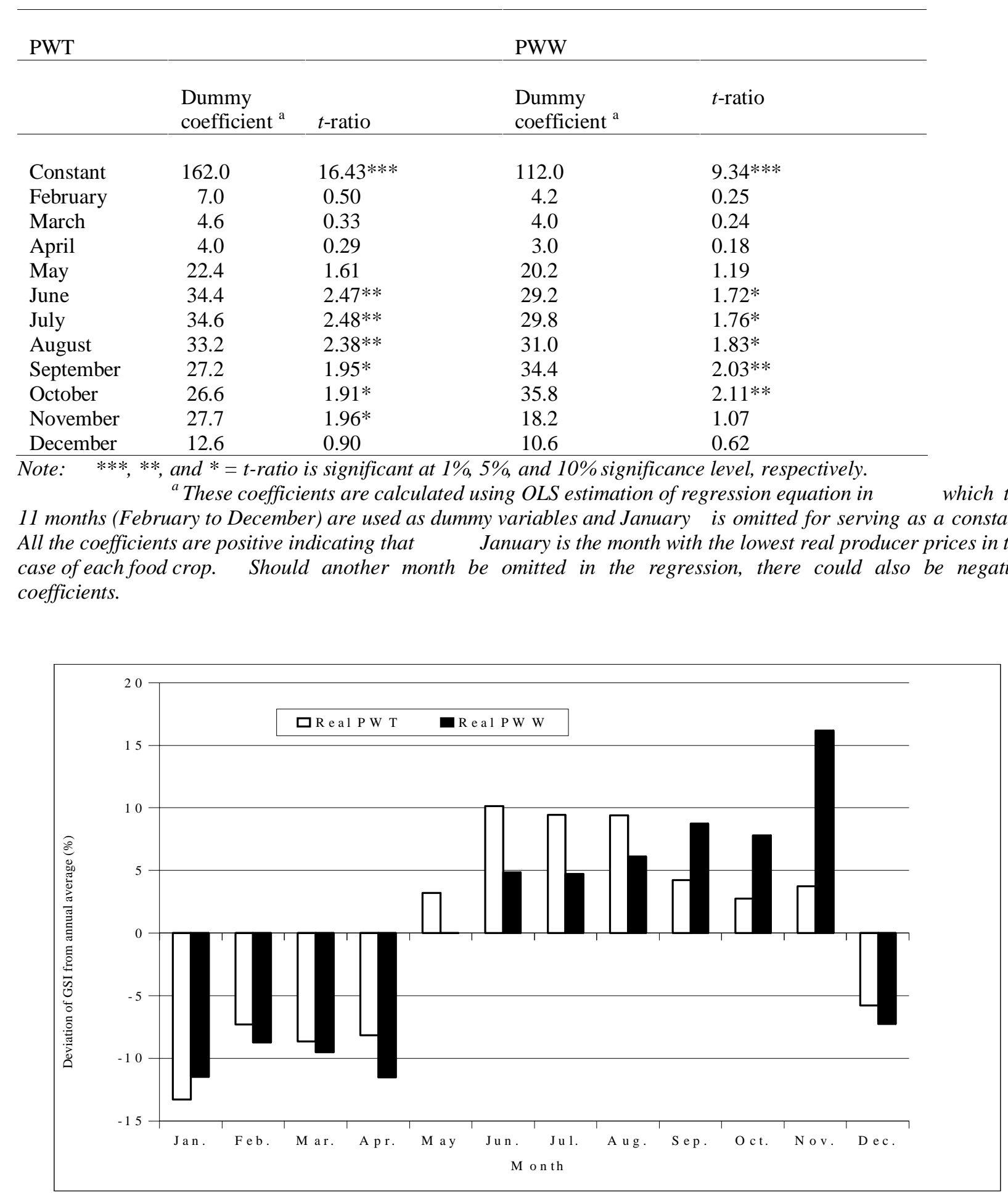

Figure 1. GSI for white teff and White wheat (1996M1-2000M12) 
As shown in Figure 1, the position of the deviation of each month's GSI value from the annual average provides sufficient evidence in confirmation of the results shown in Table 1. Negative deviation in the GSI of a month from the annual average indicates that the price observed in that month is lower than the annual average price and positive deviation indicates that the price observed in that month is higher than the annual average price.

Based on the evidences obtained from the above two approaches employed to understand the seasonal properties of producer prices, December, January, February, March, and April can be considered as months with relatively low producer prices and June, July, August, September, and October as months with relatively high prices for white teff and white wheat. In circumstances when the cash demand of the farmers of such crops overlaps with such months in which producer prices are relatively low, producer prices will decline further to make it very difficult for the farmers even to cover production costs incurred in the production process of the crops. Hence, overlapping seasonality between the farmers' high cash demand, on the one hand, and the harvest and immediate postharvest seasons for their crops, on the other, becomes a pull factor to producer prices - adding benzene to fire. If farmers happen to sell a large proportion of their products during such months, the low prices they receive will discourage them not to increase their production and the impact of the market reform process will remain limited in terms of achieving food selfsufficiency and food security in the country.

\section{Farmers' Perceptions about Price Movements and the Seasonal Properties of their Cash Demand}

In addition to their resource bases and production objectives, farmers' perceptions about the prices of their products are very important in terms of guiding their production and marketing decisions. Difference in the perceptions of any two farmers about the price level of products would possibly lead them to different production decisions even if they might have similar resource base and production objective. On the other hand, it is possible that any two farmers with different resource bases and production objectives but with similar perceptions about the price level of products and about the resulting risk or benefit take similar production decisions. In this section, survey results on farmers' perceptions about the month-to-month variations of producer prices are presented. The need to know farmers' perceptions about the prices of their products is related to the critical need to know what bearings such perceptions have on the production and marketing decision making behaviours of the farmers. Specifically, farmers' perceptions about the monthly variations in the producer prices of the two crops are thought to influence their storage and marketing decisions.

\subsection{Farmers' Perceptions about Monthly Price Variations}

As it is mentioned under the descriptive study, producer prices of white teff and white wheat, like any other agricultural product, have seasonal patterns. Though the knowledge about such seasonal patterns of producer prices does not necessarily help farmers to plan and change their production period accordingly, because production period depends on environmental factors, it definitely helps them to plan their storage and marketing activities. Therefore, appropriate perceptions by farmers about the seasonal patterns of producer prices of their products are important in terms of guiding their storage and marketing decisions.

What are the months in which farmers perceive producer prices to be too high and too low? ${ }^{4}$ Farmers perceive producer prices of both crops to be too high in August, July, and June and to be too low in January, December, and February, in their decreasing order of importance. Such perceptions of farmers about the seasonal patterns of producer prices (concerning the low price scenarios) coincide with the results obtained from the descriptive study on the time series price data. With regard to the high price scenarios, too, there is a similarity between the results obtained from the descriptive study and those from the survey study in that the months identified by the survey study as months with high producer prices, i.e., June, July, and August, fall within the range of those months identified by the descriptive study as months with high real producer price indices (June, July, August, September, October, and November). One exception in this aspect is that November is the month with the highest real producer price index for white wheat, in the descriptive study, while it is August in the survey study. This difference might be attributed to the fact that the descriptive study used real prices while farmers' perceptions used in the survey are based on nominal prices.

\subsection{Seasonal Properties of Farmers' Cash Demand}

Generally speaking, months perceived by the farmers as those with low and high producer prices fall within the domain of those months identified by the descriptive study as months with low and high producer price indices, respectively. In view of this fact, it would be recommended, without fallacy, that storage is feasible in December, January, and February (when the producer prices are low) and selling is feasible in June, July, and August (when the producer prices are high), for both products. Getnet et al. (2005) have shown that grain storage at the level of such smallholder farmers is economically feasible during December, January, and February. Exploitation of the advantages from such 
timing of storage and selling activities becomes possible provided that those factors that put farmers into selling their crops during the months with low producer prices are manipulated. Farmers have compelling reasons that put them into selling their products during such months of low producer prices with no possibility to postpone the crop sales. The survey results show that farmers, in spite of their perception of low producer prices in these months, sell the largest quantity of their marketable white teff and white wheat in January, December, and February, in their decreasing order of importance (see Figure 2).

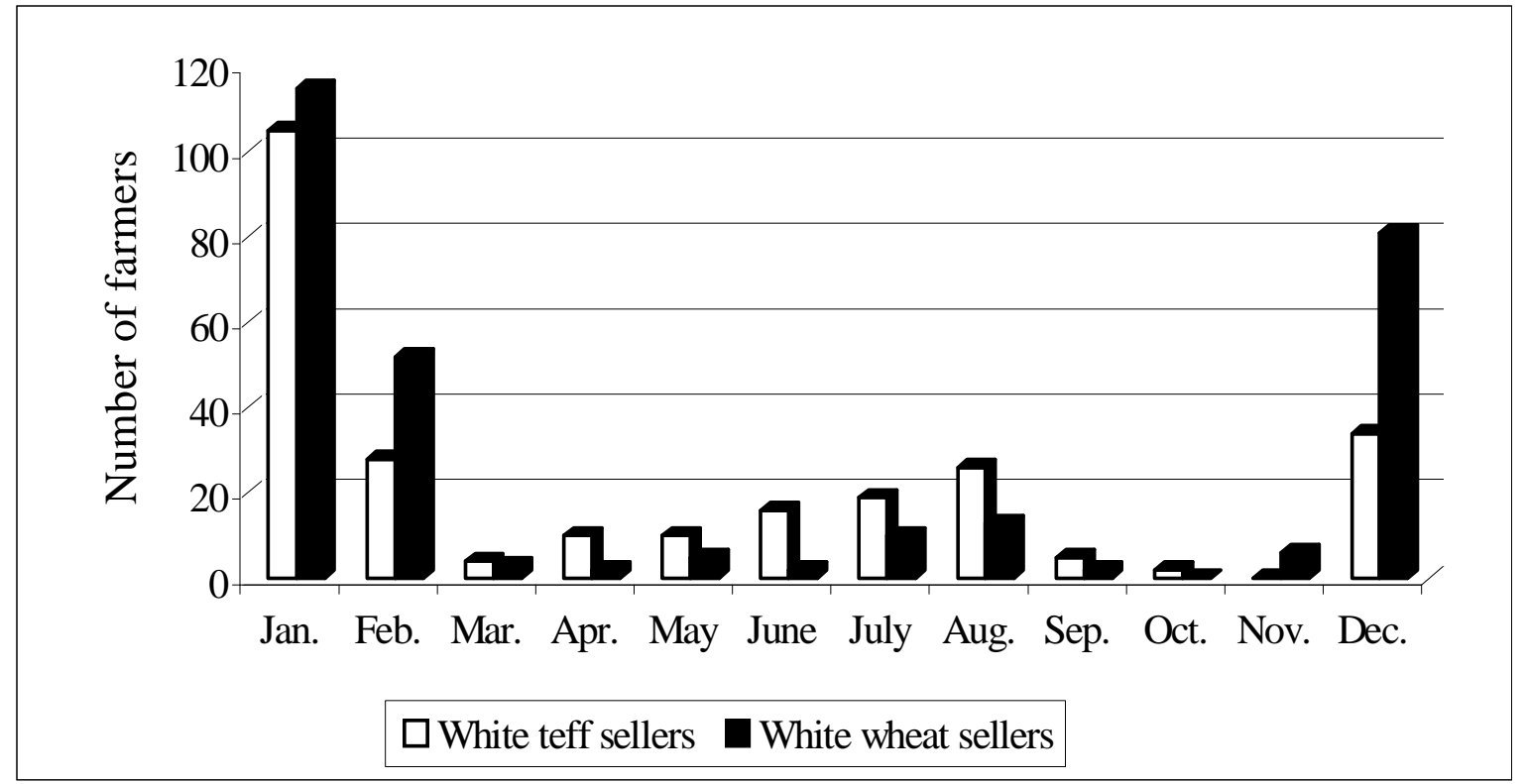

Figure 2. Farmers' responses on the timing of their white teff and white wheat sale

It is important, therefore, to identify the reasons for which farmers are forced to sell their products during such months in which producer prices are relatively low, in spite of their knowledge about the nature of the seasonal price variations that turn against their advantage in December, January, and February. If these factors are subject to manipulation, both at the level of the farmers and government, the identification could help farmers to benefit from appropriate timing of their storage and selling activities according to the seasonal behaviours of prices. In order to fulfil this, the survey study tries to identify the reasons for which farmers are forced to sell their products during such months in which producer prices are low. According to the survey results, land use tax and fertilizer loan payment ${ }^{5}$ are found as the main reasons that put farmers into selling their crops during the respective months in which producer prices are low. For crop sales constitute the most important sources of family cash income in such smallholder farm households, farmers opt to crop sales when they are required to settle their land use tax and fertilizer debt obligations. Since this is well known by the Office of Finance and Economic Development (OFED) and by the Office of Agriculture Development (OAD), Ambo district, which collect land use tax and advance the fertilizer credit, the land use tax and fertilizer debt collection are intentionally scheduled from November to April, with more emphasis given to January and February in the case of the OAD for fertilizer debt collection (according to the survey results from the rapid appraisal). Such seasonality of the schedule for land use tax and fertilizer debt collection is rationalized on the crop calendar of farmers (see Table 2). Key informants from the OFED and from the OAD confirm that the schedule is not subject to any revision for it must necessarily coincide with the crop calendar of farmers in order to make the farmers settle such cash obligations from crop sales ${ }^{6}$. The crop calendar, in turn, depends on the biological nature of the agricultural production in which crop harvesting and threshing in Ambo and in most parts of Ethiopia are practiced from early November to late January, hence the scheduled land use tax and fertilizer debt payment from November to April. 
Table 2. Crop calendar and schedule for land use tax and fertilizer debt payment around Ambo

\begin{tabular}{l}
\hline \\
\hline
\end{tabular}

Source: Author's survey results (2002); OPED (1998).

Note: Harvesting season. Threshing season.

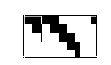

In addition to stating their own reasons that put them into selling large quantities of crops in those months in which they perceive producer prices to be low, farmers were also asked to state other reasons which they believe make producer prices too low in December, January, and February. Their collective responses to these questions show poor market access and excess production (whenever there is favourable weather condition) as the third and fourth important factors, for both crops. Such factors supposed to be responsible for the low producer prices in December, January, and February are rated as shown in Table 3, based on farmers' perceptions.

Table 3. Factors responsible for low producer prices of white teff and white wheat in December, January, and February

\begin{tabular}{|c|c|c|c|c|c|c|c|c|c|c|}
\hline & \multicolumn{5}{|c|}{ White teff } & \multicolumn{5}{|c|}{ White wheat } \\
\hline & $1^{\mathrm{st}}$ & $2^{\text {nd }}$ & $3^{\text {rd }}$ & $4^{\text {th }}$ & $5^{\text {th }}$ & $1^{\mathrm{st}}$ & $2^{\text {nd }}$ & $3^{\text {rd }}$ & $4^{\text {th }}$ & $5^{\text {th }}$ \\
\hline Fertilizer debt & 122 & 65 & 0 & 0 & 0 & 120 & 63 & 2 & 0 & 0 \\
\hline Tax payment & 56 & 111 & 19 & 1 & 0 & 52 & 106 & 28 & 0 & 0 \\
\hline Poor market access & 7 & 12 & 79 & 22 & 1 & 12 & 17 & 68 & 21 & 1 \\
\hline Excess production & 2 & 0 & 27 & 51 & 0 & 2 & 0 & 26 & 48 & 0 \\
\hline Poor storage facility & 0 & 0 & 2 & 0 & 2 & 0 & 0 & 3 & 0 & 5 \\
\hline
\end{tabular}

Note: $\quad 1^{\text {st }}=$ Highly important factor and $5^{\text {th }}=$ Less important factor.

Cell entries refer to the number of scores marked for the particular factor under each rate.

Bold figures in each column indicate the factor that is perceived to be most important.

Though majority of the farmers sell a large proportion of their marketable teff and wheat products in December, January, and February, typically for settling land use tax and fertilizer debt, it is found that 
a considerable number of them sell their products also in July and August (see Figure 2). According to the survey results, the main reason of these farmers for delaying the sell of their products until July and August is the need to benefit from high prices for their commodities in these months. This shows that some farmers perform storage functions and are also aware of the benefits they could gain from postponing the sell of their products. For majority of the farmers, however, this is not easy as the immediate problem of settling land use tax and fertilizer debt obligations, in December, January, and February, is irrefutable.

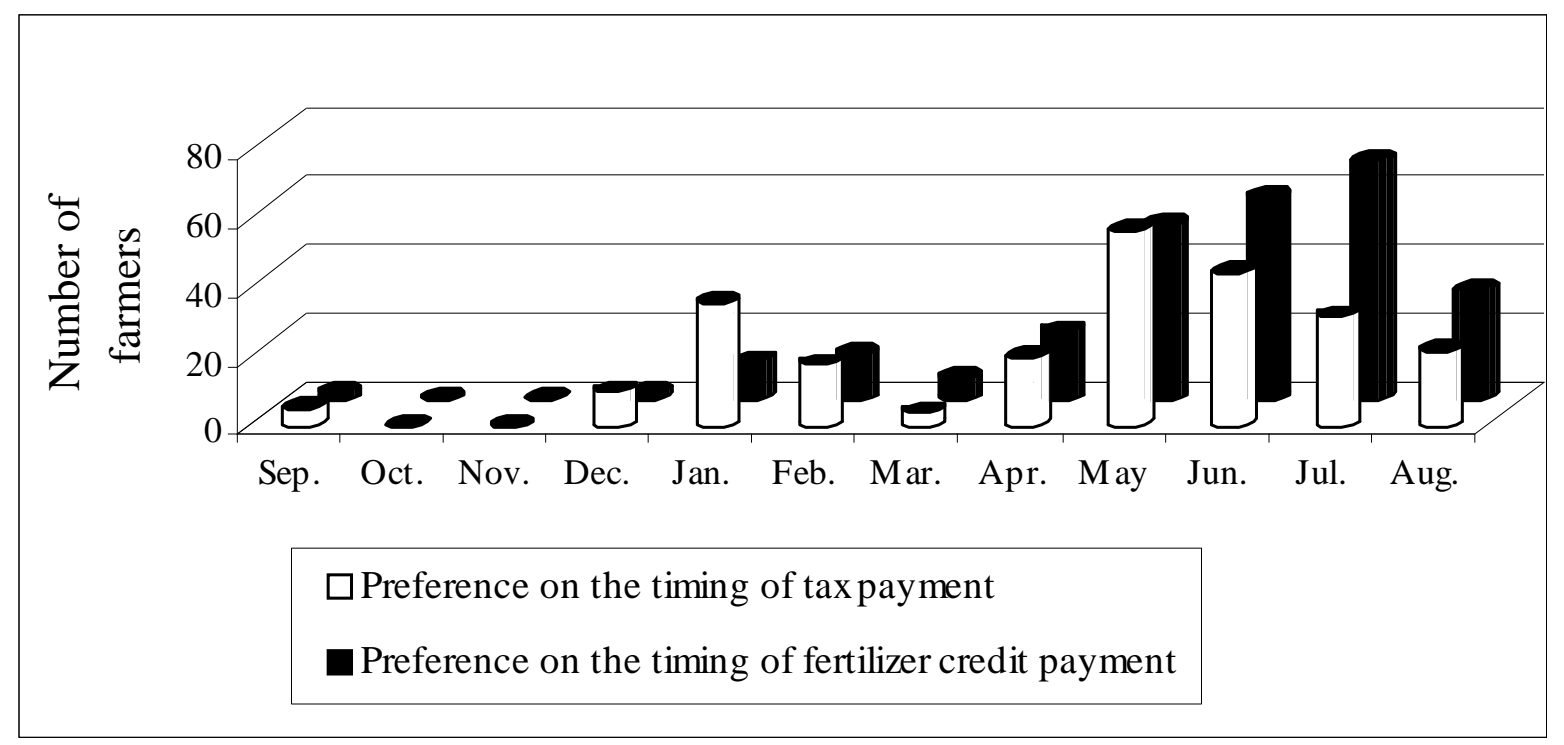

Figure 3. Farmers' preferences on the timing of land use tax and fertilizer debt payment

If given the chance to postpone the payment of their land use tax and fertilizer debt obligations, therefore, it can be assumed that farmers are rational and tend to exploit the advantage of high crop prices in the late months (May, June, July, August, September, and October) by delaying their crop sell until then. Their response to a question on their preference for the timing of land use tax and fertilizer debt payment shows months from May to August as the first four months of preference (see Figure 3). These months coincide with those months of high producer prices of the two crops, as revealed both from the descriptive study results and from the farmers' perceptions about price movements. Unless it has negative implications on the tax collection and revenue schemes of the government and technical and budgetary influences on the creditors of fertilizer debt, therefore, rescheduling land use tax and fertilizer debt payment according to farmers' preferences would benefit farm households in terms of better prices to their crops. However, the results from the rapid appraisal survey concerning this issue show that the OFED and OAD do not seem flexible to reschedule the collection of fertilizer loan and land use tax, indicating that policy makers need to reconsider it if possible.

\section{Conclusions}

Rooted in the biological nature of agricultural production, the harvest and supply of agricultural products are generally seasonal. In the absence of a well developed marketing system to perform processing, storage, and transportation functions, the seasonal supply of agricultural products affects product prices negatively during the harvest and immediate post-harvest seasons. In addition to the seasonal supply of products due to the biological nature of their production, seasonality of farmers' cash demand contributes to further decline of product prices if it overlaps with the harvest and immediate post-harvest seasons.

The case of white teff and white wheat investigated in this study reveals overlapping seasonality between the harvest and immediate post-harvest seasons (December, January, February, March, and April), on the one hand, and the seasons of high cash demand by farmers, on the other. Obviously, the overlap is expected to further reduce the price of products received by the farmers, since price is already low as a result of excess supply during such seasons. From policy making point of view, raising and stabilizing farmers' income from such crop sales would possibly be approached through shifting the seasons of high cash demand by the farmers. This, in turn, requires knowledge about those factors that raise the cash demand of farmers during the harvest and immediate post-harvest seasons, for possible intervention of manipulation. In the study area, the survey results show that land use tax payment and fertilizer debt payment (scheduled from November to April) are the first two most important factors that raise the cash demand of farmers during the harvest and immediate post-harvest 
seasons of the two crops. Scheduling land use tax payment and fertilizer debt payment during the harvest and immediate post-harvest seasons ends in adding benzene to fire, in which the already low prices of the crops due to their high seasonal supply tend to further decline.

Provided that it has no or only a very limited impact on the government tax administration and revenue and on the default rate of fertilizer debt payment, it is advisable to reschedule the time of land use tax collection and fertilizer debt payment from the harvest and immediate post-harvest seasons to the lean seasons (June, July, August, September, and October). An alternative would be also to create a mechanism of cash earning to the farmers that do not put them in a position of selling their crops during the harvest and immediate post-harvest seasons. In this regard, the recent initiative of the Ethiopian government to issue a certificate to a farmer upon his delivery of grains to a stocking centre, for the certificate to be used as a guarantee to borrow money to satisfy his immediate cash demand, is a commendable strategy. Moreover, establishing and promoting agricultural marketing cooperatives would be helpful to member farmers in terms of providing better marketing opportunities for their products by allowing them to generate immediate cash during the harvest and immediate post-harvest seasons and by enabling them to get dividends from the profits generated as a result of delayed sell of the grains stored by the cooperatives during the harvest and immediate post-harvest seasons. To the extent that their economic incentives from the production and marketing of such crops are promoted using the different mechanisms mentioned above, the farmers will increase their agricultural production and productivity, with positive contribution to the welfare of the farm households, in particular, and to the food self-sufficiency and food security objectives of the country, in general.

\section{References}

Alderman, H. and Shively, G. 1996. Economic reform and food prices: Evidence from markets in Ghana. World Development 24(3): 521-534.

Badiane, O., 2000. The Effect of Liberalization on Food Markets in Africa. In: van Tilburg, A., Moll, H.A. and Kuyvenhoven, A. (eds.), Agricultural Market Beyond Liberalization. Kluwer Academic Publishers, USA.pp. 1956.

Getnet, K. 2005. Behaviour of farmers towards price changes beyond liberalization of grain markets in Ethiopia. Ph.D dissertation, Ghent University, Belgium.

Getnet, K., Verbeke, W. and Viaene, J. 2005. Feasibility of on-farm commercial grain storage in the smallholder agriculture of Ethiopia. Outlook on Agriculture 34: 41-47.

Kherallah, M., Delgado, C., Gabre-Madhin, E., Minot, N. and Johnson, M.2000. Agricultural Market Reforms in Sub-Saharan Africa: A Synthesis of Research Findings. Revised Draft, IFPRI, Washington, D.C.

Sahn, D.E., Dorosh, P. and Younger, C. 1996. Exchange Rate, Fiscal and Agricultural Policies in Africa: Does Adjustment Hurt the Poor? World Development 24(4):719747.

Seppala, P. 1997. Food Marketing Reconsidered: An Assessment of the Liberalization of Food Marketing in Sub-Saharan Africa.UNU World Institute for DevelopmentEconomics Research, Research for Action 34, Helsinki, Finland.

Thorbecke, E. 2000. Agricultural Markets Beyond Liberalization: The Role of the State.In: van Tilburg, A., Moll, H.A. and Kuyvenhoven, A. (eds.), Agricultural Markets Beyond Liberalization. Kluwer Academic Publishers, USA. pp. 19-56.

Valdes, A. 1996. Surveillance of Agricultural Price and Trade Policy in Latin America during Major Policy Reforms. World Bank Discussion Paper No. 349, World Bank, Washington, D.C. 
Appendix I. Isolation of seasonal indices (GSI) using the classical multiplicative

model of time series decomposition

In a classical multiplicative model of time series decomposition, price series $P_{i}$ could be decomposed into four component parts as follows:

$$
\begin{aligned}
& P_{i}=T_{i} \times C_{i} \times S_{i} \times E_{i} \\
& \text { where } \quad P=\text { price } \quad T=\text { trend component } \\
& C=\text { cyclical component } \quad S=\text { seasonal component } \\
& E=\text { irregular component } \quad i=\text { time period }(i=1,2, \ldots, n)
\end{aligned}
$$

Calculating the centred moving average values ( $C M A)$ of a series over a certain time period, for example, $C M A^{n}(n=12)$ with monthly data, completely eliminates the seasonal price movements ( $S_{i}$ and $E_{i}$ components) observed in the $P_{i}$ series over the twelve months. Hence, if $C M A$ removes the irregular components and seasonal movements of a price time series, it follows that $C M A^{12}$ figures are without $S_{i}$ and $E_{i}$ components. That is, $C M A_{i}^{12}$ reflects only the trend and cyclical components $\left(P_{i}=T_{i} \times C_{i}\right)$. Therefore, dividing (1) to $C M A^{12}$ helps to obtain the ratio-to-moving average values for each month, which is referred to as the seasonal index $\tilde{S}_{i}$.

$$
P_{i} / C M A^{12}=\tilde{S}_{i}=(T C S E / T C)_{i}=S_{i} E_{i}
$$

Since the seasonal index $\left(S_{i}\right)$ under (2) constitutes both the seasonal component $(S)$ and the irregular component $(E)$ of the series, it is important to calculate the Grand Seasonal Index ( $G S I$ ) to obtain the pure seasonal component. The GSI, which is an average of each month's seasonal indices, removes all random movement or irregular component of the time series data and filters out the pure seasonal component. Accordingly, there are twelve GSI (one for each month, calculated as average) and these twelve figure series are adjusted in such a way that they add up to 1200 , when each month's value is expressed in percentage.

$$
G S I_{i}=\tilde{S}_{i} \times\left[1200 / \sum_{i=1}^{12} \tilde{S}_{i}\right]
$$

\section{End Note}

where $\quad \tilde{S}_{i}$ is the average seasonal index for month $i$.

\footnotetext{
${ }^{1}$ January is considered as the reference month with the lowest producer prices for white teff and white wheat since it is the month in which these crops are harvested and threshed.

${ }^{2}$ In case the reference month is with the highest possible monthly price, the rest of the months are expected to depart from it negatively with different magnitude of departure depending on their distance from it.

${ }^{3}$ See Appendix I on how the classical multiplicative model of decomposition is used to isolate the seasonal components (GSI).

4 "Too high" and "too low" prices, as used here, are not quantified objectively, rather they are used subjectively as relative concepts to refer to price levels that deviate too much from the levels acceptable as normal.

${ }^{5}$ Because farmers can not pay the full price to acquire inorganic fertilizers (such as DAP and UREA) during the production seasons (mainly June and July), the widely used practice is for the government to pay fertilizer prices to the suppliers on the farmers' behalf and for the farmers to take the fertilizers on credit basis with the agreement that they repay the loan from crop sales ahead during the harvest and immediate post-harvest seasons.

${ }^{6}$ As an alternative to escape low seasonal prices, experts from the OFED, Ambo district, suggest that farmers better store their crops during such months of land use tax and fertilizer debt payment and settle their obligations from other income sources such as livestock sales. However, this will not be an easy option for all farmers since the livestock base of farm families may not be necessarily dependable.
} 